DOI: $10.17516 / 1997-1370-0753$

УДК 343.37:504.122

\title{
The Justification for Criminalization of "Simple" Illegal Forest Plantation Felling (Part 1, Article 260 of the Criminal Code of the Russian Federation)
}

\author{
Irina V. Shishko and Svetlana V. Starovatova* \\ Siberian Federal University \\ Krasnoyarsk, Russian Federation
}

Received 04.03.2021, received in revised form 30.04.2021, accepted 11.05.2021

\begin{abstract}
Taking into account that the problem of illegal forest felling in Russia has not been solved so far, the article studies the justification for criminalization of illegal forest felling in considerable amount provided for under Part 1, Article 260 of the Criminal Code of the RF ("simple" illegal felling of forest plantations). According to the Criminal law theory de facto such offence aspires to complete or partial decriminalization, however, de jure such offence has been significantly criminalized.

Referring to the theory of criminalization and decriminalization, the authors defined that criminal public danger possesses 2 subsystems (object and damage), "simple" illegal felling has got only one so-called subsystem, which is valuable object. The second subsystem (damage) is absent. The authors determined the significant amount of illegal felling by analyzing the judicial practice which in turn fails to meet the requirements of the legislation. In order to prosecute somebody for illegal felling it is enough to prove that the only one pine tree $26 \mathrm{~cm}$ in diameter and 16 meters high has been illegally cut down. Offenders are more often prosecuted for illegal felling in significant amount (Part 3, Article 260 of the Criminal Code of the RF) than for offence provided for under Part 1, Article 260 of the Criminal Code of the RF. As for the total number of verdicts rendered based on Part 2 and Part 3 of the given article, they are twice higher than the number of verdicts based on Part 1, Article 260. Nevertheless, the circumstances that are being introduced into this law as qualifying cannot go with the absolute majority of offences and become a kind of "standard norm" for them. The elements which characterize the overwhelming majority of the certain types of offences should be acknowledged as the essential elements of an offence. In this context authors assume that such indicator as the significant amount of felling should be considered as a criminalizing element of illegal felling. "Simple" illegal forest felling is to be decriminalized, so that sanctions of Part 1 and Part 2 of Article 8.28 of the Code of Administrative Offences are to be amended as well: fines should be increased, basic alternative kind of punishment should be implemented such as community service as well as supplementary punishment in a form of confiscation of work tool or the target of administrative offence.
\end{abstract}

\footnotetext{
(C) Siberian Federal University. All rights reserved

* Corresponding author E-mail address: ir-vic02@yandex.ru, sstarovatova@sfu-kras.ru ORCID: 0000-0002-9179-1113 (Shishko); 0000-0002-3394-9728 (Starovatova)
} 
Keywords: forest plantations, illegal felling in considerable amount, impropriety of overcriminalization, dominance of aggravating corpus delicti in practice, the necessity of decriminalization.

Research area: criminal law, criminology, penal law.

Citation: Shishko, I.V., Starovatova, S.V. (2021). The justification for criminalization of "simple" illegal forest plantation felling (Part 1, Article 260 of the Criminal Code of the Russian Federation). J. Sib. Fed. Univ. Humanit. Soc. Sci., 14(5), 702-717. DOI: 10.17516/1997-1370-0753.

\title{
Об обоснованности криминализации «простой» незаконной рубки лесных насаждений (ч. 1 ст. 260 УК РФ)
}

\author{
И.В. Шишко, С.В.Староватова \\ Сибирский федеральный университет \\ Российская Федерация, Красноярск
}

\begin{abstract}
Аннотация. С учетом нерешенности в России проблемы незаконной рубки в статье исследуется обоснованность криминализации незаконной рубки в значительном размере, предусмотренной ч. 1 ст. 260 УК РФ (простая незаконная рубка или основной состав). В теории уголовного права это деяние претендует на полную или частичную декриминализацию, в то время как де-юрэ произошла его существенная докриминализация.

Обращение к теории криминализации/декриминализации позволило авторам установить, что из двух необходимых «подсистем» криминальной общественной опасности (объект и вред) простой незаконной рубке присуща только одна ценный объект. Вторая «подсистема» - вред (ущерб) - отсутствует. Установленный значительный размер незаконной рубки стал результатом учета судебной практики, не соответствующей требованиям законодательства. Для привлечения к уголовной ответственности в настоящее время достаточно установить незаконную рубку даже одной сосны диаметром 26 см и высотой 16 м.

Необоснованность криминализации простой незаконной рубки подтверждает и правовая статистика за 4 года. К уголовной ответственности за незаконную рубку в особо крупном размере (ч. 3 ст. 260 УК РФ) привлекают чаще, чем за деяние, предусмотренное ч. 1 ст. 260 УК РФ, а общее число приговоров по второй и третьей частям этой статьи в два и более раза больше количества приговоров по части первой. Кроме того, в 2019 г. количество приговоров только по части третьей почти в 2 раза превышает количество приговоров по части первой.

Однако обстоятельства, вводимые в закон в качестве квалифицирующих, не могут сопровождать абсолютное большинство преступлений, быть «нормой» для них. Признаки, характеризующие подавляющее число проявлений определенного вида преступления, должны признаваться признаками основного состава преступления. В связи с этим, считают авторы, криминообразующим признаком незаконной рубки должен быть не значительный, а крупный размер. Простая незаконная рубка подлежит декриминализации, а санкции частей первой и второй ст. 8.28. КоАП
\end{abstract}


требуют соответствующей корректировки: увеличения размеров штрафа, включения альтернативного основного вида наказания - обязательных работ - и дополнительного наказания (в часть вторую указанной статьи) - конфискации орудия совершения или предмета административного правонарушения.

Ключевые слова: лесные насаждения, незаконная рубка в значительном размере, ошибочность докриминализации, доминирование квалифицированных составов на практике, необходимость декриминализации.

Научная специальность: 12.00.08 - уголовное право, криминология, уголовноисполнительное право.

\section{Введение}

В России незаконная рубка лесных насаждений признается застарелой, но до конца так и не решенной проблемой (Soveshchanie o razvitii i dekriminalizacii..., 2020). По официальным данным, ущерб от незаконной рубки лесных насаждений в нашей стране составляет 11-12 млрд рублей в год (Schyotnaya palata ocenila ushcherb..., 2019), а объем ущерба, по экспертным оценкам, равен 40-50 млн куб. м древесины (Nezakonnye vyrubki rossijskogo lesa..., 2017). Не случайно масштабы нелегальной заготовки леса в России называют угрожающими.

Могут ли решить эту проблему традиционные уголовно-правовые способы - докриминализация или повышение санкций за преступную незаконную рубку? Для ответа на этот вопрос необходимо исследовать обоснованность криминализации преступления, предусмотренного ч. 1 ст. 260 Уголовного кодекса РФ: именно она устанавливает ответственность за ту незаконную рубку лесных насаждений, которая должна быть наиболее распространенной.

Обоснованность криминализации незаконной рубки в целом исследователи вниманием не обошли: к ней обращались в своих работах, в частности, И.Г. Травина, И. А. Фиськов, И. В. Попов.

Что касается криминализации «простой» незаконной рубки, то мнения о ее обоснованности разошлись.

Так, по мнению В.Н. Каплунова, размеры, предусмотренные в примечании к ст. 260 УК РФ и характеризующие ущерб, причиненный лесным насаждениям, «явно не отвечают современным экономическим реалиям». Он предлагает повысить размер ущерба, соответствующий значительному размеру незаконной рубки, в 10 раз, обозначив его как превышающий 50 тыс. рублей (Kaplunov, 2011), что, по сути, является предложением полностью декриминализовать незаконную рубку, причинившую ущерб на сумму в 50 тыс. рублей и менее (т. е. «простую» незаконную рубку лесных насаждений).

Отрицательно относится к криминализации незаконной рубки, причинившей ущерб на сумму свыше 5 тыс. рублей, и И. А. Конфоркин. Однако в отличие от предыдущего автора он предлагает не увеличить размер (а значит, и ущерб) в 10 раз, а вернуться к прежнему размеру, превышающему 10 тыс. рублей (Konforkin, 2009).

Частичная декриминализация незаконной рубки лесных насаждений представляется правильной и другим исследователям. К примеру, Д. Б. Чураков пишет, что «наряду с общественно опасными совершается множество противоправных деяний в сфере лесных отношений, которые не несут в себе особой общественной опасности, так как совершаются лицами впервые, по незнанию и не с целью наживы, а для собственных бытовых нужд, в связи с чем оправдана административная преюдиция по таким случаям. Это предотвратит десоциализацию «случайных» лиц, привлекаемых к ответственности» (Churakov, 2017).

«Простая» незаконная рубка «претендует» на декриминализацию и в работах, 
посвященных общей проблеме криминализации - декриминализации.

К примеру, по мнению Н.Ф. Кузнецовой, все преступления небольшой тяжести входят в «основной массив для декриминализации» (Kuznetsova, 2010). Как видно, к этому «массиву» относится и незаконная рубка лесных насаждений (ч. 1 ст. 260 УК): максимальная санкция за нее - лишение свободы на срок до 2 лет.

Вместе с тем уже упомянутый сторонник частичной декриминализации «простой» незаконной рубки Д.Б. Чураков отмечает, что «основаниями криминализации посягательств на лесные ресурсы являются, в первую очередь, экологические факторы, что обусловлено сокращением лесов, высоким уровнем и нарастающей интенсивностью антропогенного, в том числе криминального, воздействия на них. В связи с этим уголовная политика государства в сфере лесопользования должна быть экологически обоснованной, развивать тенденцию к одновременному ужесточению и дифференциации уголовной ответственности в отношении деяний, приводящих к уничтожению или повреждению лесных экосистем, а равно создающих угрозу причинения такого вреда, пропорционально степени их общественной опасности» (Churakov, 2017). С ним солидарны В. А. Кулакова и Т.Б. Чердакова (Kulakova, Cherdakova, 2020).

По мнению Г.Н. Жеребкина, «для усиления эффективности борьбы с незаконными рубками прежде всего необходимо усилить санкцию за данный вид преступлений» (Zherebkin, 2011).

Представление о том, что «простая» незаконная рубка нуждается в дополнительной криминализации, разделяет и законодатель. Об этом свидетельствует легальное толкование значительного размера - криминообразующего признака, используемого в диспозиции ч. 1 ст. 260 УК. Так, если в 2003 г. им признавался ущерб, причиненный лесному фонду и не входящим в лесной фонд лесам, исчисленный по утвержденным Правительством Российской Федерации таксам, превышающий 10 тыс. рублей
(Federal'nyj zakon, 2003: 162), то в 2008 г. значительным размером стал признаваться ущерб, в два раза меньший, т. е. превышающий 5 тыс. рублей (Federal'nyj zakon, 2008: 145), что повлекло криминализацию незаконной рубки, причинившей ущерб свыше 5 тыс. рублей и до 10 тыс. рублей.

Дополнительная частичная криминализация произошла и в 2015 г., однако она стала результатом изменений не в Уголовном, а в Лесном кодексе РФ: определение рубок лесных насаждений в последнем было расширено (Federal'nyj zakon, 2017: 206) за счет включения в него всех процессов валки, в том числе процессов спиливания, срубания, срезания (ранее рубками признавались только эти три процесса), а также иных технологически связанных с ними процессов (трелевку, частичную переработку, хранение древесины в лесу). С учетом того, что в объективную сторону вошел больший круг действий, а значительным размером стал признаваться меньший ущерб, докриминализацию в 2008-2015 гг. следует признать весьма существенной: преступными могут быть валка, переработка, хранение или трелевка даже одной сосны.

\section{Постановка проблемы}

Обоснована ли дополнительная криминализация «простой» незаконной рубки в таком размере? Почему незаконная рубка лесных насаждений, предусмотренная ч. 1 ст. 260 УК РФ, в уголовно-правовой науке претендует на частичную или полную декриминализацию, но де-юре эволюционирует только в сторону докриминализации? Ответы на эти вопросы крайне важны в настоящее время, когда разрабатывается комплекс эффективных мер противодействия незаконной рубке.

\section{Незаконная рубка в значительном размере через призму теории криминализации}

Для ответа на поставленные вопросы прежде всего необходимо обратиться к теории криминализации.

К исследованию вопроса криминализации (как и декриминализации) в науке уго- 
ловного права обращались многие ученые: П. С. Дагель, И. М. Гальперин, Г. А. Злобин, Н.Г. Иванов, К. Кенни, В.Н. Курляндский, А.И. Коробеев, В.Н. Кудрявцев, Н.А. Лопашенко, А.В. Наумов, В.И Плохова, Л.М. Прозументов, А. В. Шеслер, П.А. Фефелов и др. Однако к разрешенным его отнести по-прежнему нельзя. Не совпадают определение криминализации, представление об основании криминализации, ее принципах (условиях, критериях). Более того, даже авторы, признающие основанием криминализации общественную опасность деяния (Kuznetsova, 2010), определяют ее по-разному.

Вместе с тем исследование авторских позиций позволяет выделить основания и условия криминализации, разумность которых не вызывает сомнений и которые в силу этого признаются большинством криминалистов. К их числу относится общественная опасность, возможности системы уголовной юстиции, превышение ожидаемых положительных последствий криминализации ее отрицательных последствий, невозможность борьбы при помощи менее репрессивных, не уголовноправовых мер (или невозможность защиты более мягкими мерами), относительная распространенность, неблагоприятная динамика конкретных деяний и исторические традиции.

Основанием криминализации, по мнению едва ли не большинства авторов, является общественная опасность деяния (Kuznetsova, 2010; Lesnikov, Lopashenko, 2005; Tobolkin, 1983; Prozumentov, 2009; Prozumentov, 2014). А. И. Коробеев, Н. А. Лопашенко, А. М. Николаев, В. И. Плохова называют общественную опасность одним из оснований криминализации, но в ряду оснований указывают еe первой (Polnyj kurs ugolovnogo prava, 2008; Lopashenko, 2014; Nikolaev, 2010; Plohova, 2003).

Мы считаем общественную опасность единственным основанием криминализации, так как из ч. 1 ст. 14 УК РФ следует, что Уголовный кодекс запрещает под угрозой наказания только общественно опасное деяние. «Противоправность выражает в УК социальное свойство преступления общественную опасность» (Kuznetsova, 2010)

Известно, что понятие общественной опасности в УК отсутствует. Нет ее единого определения и в науке уголовного права. В литературе общественную опасность, как правило, называют свойством преступления причинять вред или создавать угрозу причинения вреда правоохраняемым отношениям (или интересам), именуя это свойство как содержательно-сущностное или неотъемлемое социальное.

Авторы по-разному раскрывают систему (структуру) общественной опасности. По мнению Н.Д. Дурманова, ее определяет само деяние, значение объекта преступления, причиненный деянием вред, конкретные условия места, времени и обстановки совершения деяния, элементы субъективной стороны, свойства субъекта и способ совершения преступления (Durmanov, 1948). В. В. Хилюта в структуре общественной опасности преступления, как и первый автор, выделяет объект посягательства, общественно опасные последствия, способ совершения преступления, но только один из элементов субъективной стороны (вину) и дополнительно - санкцию правовой нормы (Hilyuta, 2018).

Н.Ф. Кузнецова выделяет в этой системе еще меньшее количество подсистем, а именно четыре основных: объект, ущерб, вину и способ совершения преступления (Kuznetsova, 2010). По мнению Л.М. Прозументова, общественная опасность определяется «только объектом посягательства и его объективной стороной (и в первую очередь, реальным ущербом, созданием возможности причинения ущерба; даже место и время совершения посягательства могут повышать его общественную опасность...)» (Prozumentov, 2009; Prozumentov, 2014). Эту позицию в основном разделяет и Ю.Е. Пудовочкин. Он считает, что наличие признака общественной опасности, в первую очередь, зависит от того, чему и какой вред причиняется или создается угроза причинения (Pudovochkin, 2019). Таким образом, все авторы видят в структуре 
общественной опасности объект и причиненный деянием вред (ущерб).

На то, что «при учете характера общественной опасности преступления судам следует иметь в виду прежде всего направленность деяния на охраняемые уголовным законом социальные ценности и причиненный им вред», указал и Верховный Суд РФ, отметивший, что характер общественной опасности преступления (в отличие от ее степени) определяется уголовным законом и зависит от установленных судом признаков состава преступления.

С учетом изложенного, исследуя общественную опасность незаконной рубки лесных насаждений, мы будем опираться исключительно на такие «подсистемы», как объект и вред (причиненный или угроза которого создается).

Подчеркивая значение объекта, А.А. Тер-Акопов ст. 2 УК РФ, закрепившую наиболее значимые социальные ценности, называет даже правовой основой криминализации (Ter-Akopov, 1999). Ценность ряда объектов, отмечает Н.Ф. Кузнецова, настолько внушительна, что их всегда охраняет исключительно уголовное законодательство. К ним она относит, в частности, и основы общественной безопасности (Kuznetsova, 2010).

Однако в ч. 1 ст. 2 УК РФ среди перечисленных объектов охраны указана общественная безопасность, а не ее основы. Общественная безопасность - родовой объект преступлений, включенных в раздел IX УК РФ. Именно в этот раздел включена глава 26 «Экологические преступления», в которой размещена ст. 260. Является ли непосредственный объект незаконной рубки частью общественной безопасности, если лес ценен для человека во многих аспектах (экономическом, экологическом, географическом, эстетическом, культурном, рекреационном и иных), и нередко встречается мнение о первостепенном значении экономического аспекта (Val'kovskaya, Razgon, 2017)?

Ответ на поставленный вопрос должен быть утвердительным: важнейшим считают экологический аспект многие ав- торы (Dolgih, 2020), и именно эта позиция отражена в последовательности изложения основных принципов лесного законодательства в ст. 1 Лесного кодекса РФ. Среди этих принципов указаны «сохранение биологического разнообразия», «сохранение средообразующих, водоохранных, защитных, санитарно-гигиенических, оздоровительных и иных полезных функций лесов», а также «использование лесов с учетом их глобального экологического значения».

В условиях, когда загрязнение окружающей среды уже достигло угрожающих размеров, особое значение приобретает санитарно-гигиеническая функция леса: она проявляется в образовании кислорода и поглощении углекислого газа, выделении фитонцидов, ионизации воздуха, очистке атмосферного воздуха от пыли, токсических веществ, защите от техногенного шума.

В процессе жизнедеятельности каждое дерево поглощает из окружающей среды углекислый газ, поэтому зрелые леса огромные резервуары накопленного углерода. При вырубке таких лесов большая часть этого углерода возвращается в атмосферу, умножая накопленный $\mathrm{CO}_{2}$. Не случайно экологи считают, что естественным экологическим подходом было бы поглощение его из атмосферы и депонирование в биомассе долгоживущих растений - деревьев (Forest Europe, Unece and FAO, 2011).

В то же время при накоплении в процессе фотосинтеза 1 т древесины насаждения выделяют огромное количество кислорода. Так, 1 га лесных насаждений выделяет от 2,7 до 3,9 т кислорода. Поступление кислорода из древесного полога составляет 22,5 млн т, кустарниковым ярусом - 6,7 млн т и 5,6 млн т напочвенным покровом. Общее выделение составляет около 35 млн т, что вполне достаточно для нормального функционирования человека и других живых организмов (Esteticheskie svojstva lesov rekreacionnogo naznacheniya, 2019). Как видно, лес - это основной источник кислорода, благодаря которому мы живем.

Растения часто являются источником медицинских достижений, поэтому их по- 
теря представляет собой потерю научной возможности. Лес, считают биологи, может помочь человеку преодолеть болезни и стать долгожителем (Krutovskij, 2021), в то время как бессистемная эксплуатация лесов может привести к возникновению очагов ряда болезней (Lyameborshaj, 2005).

Леса обладают и климаторегулирующим значением. Они существенно влияют на формирование климата отдельных географических зон и районов, регулируя баланс солнечной энергии на земной поверхности и в атмосфере, циркуляцию атмосферного тепла и влаги, режим воды в озерах и реках (Novosyolov, 2016).

Деревья играют ключевую роль и в водном цикле, помогая поддерживать баланс между водой на суше и водой в атмосфере (Novosyolov, 2016): они выполняют важные водорегулирующие, противоэрозионные и водоохранные функции. С вырубкой лесов без последующего их восстановления связано изменение водного режима, увеличение поверхностного стока, что часто приводит к заболачиванию территории.

Зеленые массивы защищают от неблагоприятных последствий промышленных рубок: смыва почвы в воду, сильных весенних паводков и обмеления в летний период (Moratorij na vyrubku lesa v nerestoohrannyh zonah, 2020). Отсутствие деревьев и кустарников по берегам водоемов приводит к быстрому распространению воды на больших площадях. Во время половодий вода, не встречая препятствий, быстро стекает по поверхности почвы и значительно поднимает уровень рек, что приводит к наводнениям.

Сплошнолесосечные рубки влекут изменения химических свойств почвы. Объясняется это активными процессами нитрификации и минерализации почвы, происходящими в первые годы после вырубки леса. Они приводят к увеличению растворимости соединений алюминия и появлению его подвижных форм. В результате этого растения и некоторые почвенные микроорганизмы подвергаются угнетению, что сказывается на почвенном плодородии (Tolkach, 2015). Уменьшение или уничто- жение биологического потенциала почвы может привести к возникновению условий, аналогичных условиям пустыни.

От сокращения площади лесов страдает не только животный и растительный мир, но и само благополучие человека, потому что ухудшение условий жизни животных, уменьшение численности их популяций вызывают опосредованные или прямые негативные последствия для самого человека и общества в целом.

Без лесов жизнь на Земле была бы практически невозможна.

Вот почему в Конституции РФ закреплено, что «лес и другие природные ресурсы используются и охраняются в Российской Федерации как основа жизни и деятельности народов, проживающих на соответствующей территории» (ст. 9).

Изложенное позволяет разделить представление об основном непосредственном объекте незаконной рубки лесных насаждений как отношениях экологической безопасности в области охраны и рационального использования лесных насаждений (Selyakov, 2010; Zhevlakov, 2002; Churakov, 2017) либо как «экологической безопасности такого компонента окружающей природной среды, как дикорастущая флора; ее стабильность и природноресурсный потенциал» (Lopashenko, 2002). И, следовательно, основной непосредственный объект, без сомнения, составляет часть родового объекта - общественной безопасности.

Однако общественная безопасность названа в качестве объекта охраны и в ст. 1.2. КоАП РФ. В связи с этим нет оснований утверждать, что посягательство на этот объект охраняется исключительно уголовным правом.

\section{Вред как составная часть общественной опасности «простой» незаконной рубки}

Исследуем вторую обязательную составляющую структуры общественной опасности - вред, причиненный экологической безопасности незаконными рубками лесных насаждений. 
С учетом основного непосредственного объекта незаконной рубки причиненный ею вред должен быть, в первую очередь, экологическим. Однако точно определить такой вред невозможно (Bykovskij, 2020; Postanovleniya Konstitucionnogo Suda RF, 2015), поэтому в основу законодательного определения размера вреда положен имущественный ущерб.

По мнению специалистов, приведенные в разных источниках цифры ущерба противоречивы и не всем им можно доверять (Kuz'michev, Trushina, Lopatin, 2018). Официальные данные об ущербе уже были приведены. По данным Продовольственной и сельскохозяйственной организации Объединенных Наций, ущерб для нашего бюджета ежегодно оценивается еще выше в 13-30 млрд рублей (Nezakonnye vyrubki rossijskogo lesa..., 2017).

Что касается экологического вреда, то согласно официальной российской статистике (Ploshchad' lesnyh zemel'..., 2015) показатель лесных площадей в России с 2009 по 2013 г. упал примерно на 2,2 млн га. Эта площадь сопоставима с территорией Словении ( 20253 км²). Такое воздействие человека на окружающую среду зачастую приобретает устрашающие размеры, угрожающие существованию всего человечества как биологического вида (Yablokov, Ostroumov, 1983). Интенсивная вырубка лесов в некоторых районах Земли уже привела к эрозии, исчезновению плодородного слоя почвы, к превращению ранее зеленых массивов в пустыню.

Последствия хозяйственной и иной деятельности человека признают затронувшими основы существования самого человека, а человечество - оказавшимся на грани экологической катастрофы (Mauro Bologna \& GerardoAquino, 2020).

Такие угрожающие масштабы вреда ценному объекту, безусловно, позволяют оценивать незаконную рубку лесных насаждений как общественно опасную и требующую криминализации. Однако приведенные масштабы - это совокупная характеристика вреда. Поэтому трудно согласиться с характеристикой общественной опасности незаконной рубки как высокой (Fis'kov, 2019), особой (Proekt Federal'nogo zakona, 2008: 490497-4) или имеющей наиболее высокую степень (Dolgih, 2020; Shuplecova, 2018) независимо от размера такой рубки. Ведь незаконную рубку, не достигшую значительного размера, законодатель признает еще административным деликтом, а не преступлением.

Почему же признана преступной незаконная рубка, причинившая ущерб именно свыше 5 тыс. рублей? Для ответа на этот вопрос обратимся к проблеме разграничения административного правонарушения и преступления.

Прежде всего, отметим, что дефиниция административного правонарушения в КоАП РФ (ст. 2.1), не содержащая так называемого материального признака, вызвала дискуссию в юридической науке, в итоге которой большинство специалистов признали общественную опасность присущей и данным правонарушениям (Deryuga, 2011; Nechevin, Kolodkin, 2020; Prozumentov, 2009; Prozumentov, 2014). В связи с этим актуально не разграничение общественно вредоносного (как ранее определялось административное правонарушение) и общественно опасного деяния, а разграничение общественной опасности, присущей непреступным деликтам, и общественной опасности, требующей признания деяния преступлением (ее именуют достаточной, повышенной, достаточно высокой, либо криминальной). Поэтому основанием криминализации противоправного деяния следует считать не любую общественную опасность, а достаточную (криминальную).

Однако абсолютно точных критериев разграничения проступков и преступлений, а стало быть, преступной и непреступной «доз» общественной опасности не существует (Esakov, 2019; Ivanov, 2015; Hilyta, 2018). Совершенно очевидно, что в нашем случае не поможет и такой критерий разграничения, как способ (Ivanov, 2015; Kuznetsova, 2010): и незаконная рубка, предусмотренная ст. 8.28. КоАП, и преступная незаконная рубка совершаются одним способом. 
Вместе с тем разграничение административного правонарушения и преступления - это часть проблемы криминализации декриминализации, поэтому необходимо вновь вернуться к структуре общественной опасности. И следует констатировать, что при посягательстве административных деликтов и преступлений на один объект критерием разграничения, как правило, выступает размер ущерба. К этому выводу приходят и авторы, исследовавшие разграничение экологических преступлений и проступков (Lyasheva, 2008; Popov, 2014). И при отсутствии в теории сколько-нибудь четких представлений о том, какой размер ущерба свидетельствует о перерастании непреступной общественной опасности в преступную, исследователи чаще всего соглашаются с размером, установленным законодательно.

Однако сомнения в обоснованности размера «простой» преступной незаконной рубки и предложения о необходимости ее полной или частичной декриминализации не случайны.

\section{Необходимость декриминализации «простой» незаконной рубки}

Первый и самый веский аргумент состоит в том, что докриминализация «простой» незаконной рубки в 2008 г. была основана на ошибке.

Напомним, что криминализация незаконной рубки, причинившей ущерб на сумму свыше 5 тыс. рублей, «обязана» Федеральному закону «О внесении изменений в статью 260 Уголовного кодекса Российской Федерации и статью 8.28 Кодекса Российской Федерации об административных правонарушениях» (2008 г.). В пояснительной записке к проекту этого Закона видно, что его авторы предложили снизить нижний предел размера ущерба, определяющего значительный размер незаконной рубки лесных насаждений, заменив «свыше 10 тыс. рублей» на «свыше 5 тыс. рублей», мотивируя это «сложившейся судебной практикой по преступлениям данного вида». В пояснительной записке отмечалось, что «для исчисления размера ущерба, при котором наступает уголовная ответственность, применяется таксовая стоимость древесины без учета поправочных коэффициентов. В частности, при средней таксовой стоимости 1 куб. м древесины менее 190 рублей для квалификации деяний по ч. 1 ст. 260 УК РФ необходимо вырубить более 50 куб. м (1 ж/д вагон) древесины в лесах первой группы или особо защитных участках, либо 300 куб. м в остальных лесах. В таких объемах лес вырубается достаточно редко, и основная масса нарушителей избегает уголовной ответственности» (Proekt federal'nogo zakona, 2008: 490497-4).

Таким образом, в обоснование необходимости снижения размера ущерба, определяющего значительный размер незаконной рубки, авторы пояснительной записки сослались на судебную практику, которая опиралась только на таксовую стоимость древесины (т. е. стоимость древесины на корню) без учета поправочных коэффициентов.

Однако согласно примечанию к ст. 260 УК РФ значительным размером в ней признается ущерб, причиненный лесным насаждениям или не отнесенным к лесным насаждениям деревьям, кустарникам и лианам, исчисленный по утвержденным Правительством Российской Федерации таксам и методике. Иными словами, значительным размером должен признаваться ущерб, не ошибочно исчисленный в судебной практике, а рассчитанный в соответствии с нормативными правовыми актами Правительства РФ. В настоящее время к ним относятся: Особенности возмещения вреда, причиненного лесам и находящимся в них природным объектам вследствие нарушения лесного законодательства (далее - Особенности), утвержденные Постановлением Правительства РФ от 29.12.2018 № 1730, и Постановление Правительства Российской Федерации от 22.05.2007 № 310 «О ставках платы за единицу объема лесных ресурсов и ставках платы за единицу площади лесного участка, находящегося в федеральной собственности».

Согласно названным Особенностям размер ущерба от незаконной рубки опре- 
деляется, исходя из вида дерева, платы за единицу объема его древесины (1 плотный куб. м), лесотаксового района, деления деловой древесины по категориям крупности и разряда такс (т. е. в зависимости от расстояния вывозки древесины). При этом для определения размера вреда стоимость древесины пятидесятикратно увеличивается и применяются коэффициенты, установленные Постановлением Правительства РФ от 12.10.2019 № 1318 «О применении в 2021-2023 годах коэффициентов к ставкам платы за единицу объема лесных ресурсов и ставкам платы за единицу площади лесного участка, находящегося в федеральной собственности».

Расчет ущерба, причиненного незаконной рубкой лесных насаждений, в соответствии с перечисленными постановлениями приводит к резкому увеличению его размера. Так, из одной сосны диаметром 26 см и высотой 16 м можно получить 1 плотный куб. м деловой древесины. Ущерб от незаконной рубки такой сосны при расстоянии вывозки в 35 км в 2021 г. в Новосибирском лесотаксовом районе составит 14688 рублей $(1$ сосна * 1 куб. м * 108 рублей * 50 * $2,72)$, а в Московском лесотаксовом районе 21836 рублей.

Добавим, что и во время представления упомянутой пояснительной записки (2008 г.), когда значительным размером признавался ущерб свыше 10 тыс. рублей, действовавшие нормативные акты уже предусматривали пятидесятикратное увеличение стоимости древесины (Postanovlenie Pravitel'stva RF, 2007), и для достижения указанного размера необходимости вырубать 300 куб. м древесины не было. Достаточно было установить незаконную рубку одной описанной выше сосны.

Таким образом, частичная криминализация незаконной рубки в 2008 г. стала результатом учета судебной практики, не соответствующей требованиям законодательства (возможно, в одном субъекте РФ). И эта ошибка в снижении нижней «границы» значительного размера должна быть исправлена.
Показательно, что не разделяют представление законодателя об общественной опасности «простой» незаконной рубки и судьи. Об этом свидетельствует практика назначения наказания. Она в основном сводится к применению в отношении виновных обязательных работ, штрафа или условного лишения свободы. К реальному лишению свободы приговаривается только, 0,7-1,4 \% представших перед судом (табл. 1).

Другим «сигналом» к обсуждению обоснованности криминализации «простой» незаконной рубки стала правовая статистика за 4 года (Sudebnaya statistika RF, 2021). Она опровергает мнение экспертов, что именно граждан, нанятых для мелкомасштабной вырубки (часто по неформальным каналам), чаще всего ловят, наказывают и именно за счет них повышают процент раскрываемости преступлений в отчетности, а самая опасная и практически ненаказуемая цепочка связана с крупными компаниями (Nezakonnye vyrubki rossijskogo lesa..., 2017). Из данных табл. 1 видно, что к уголовной ответственности за незаконную рубку в особо крупном размере (ч. 3 ст. 260 УК РФ) привлекают чаще, чем за деяние, предусмотренное ч. 1 ст. 260 УК РФ, а общее число приговоров по второй и третьей частям этой статьи в два и более раза больше количества приговоров по части первой. Кроме того, в 2019 г. количество приговоров только по части третьей почти в 2 раза превышает количество приговоров по части первой. И это превышение имеет место, несмотря на то, что большинство уголовных дел (64 \%) при ущербе в 200400 тыс. рублей, причиненном лесному фонду и не входящим в лесной фонд лесам, прекращается без достаточных к тому оснований (Sharipova, 2006).

Однако «обстоятельства, вводимые в закон в качестве квалифицирующих, не могут сопровождать абсолютное большинство преступлений, быть «нормой» для них. Признаки, характеризующие подавляющее число проявлений определенного вида преступления, должны признаваться признаками основного состава преступления и учитываться при конструировании 
Таблица 1. Динамика применения мер уголовно-правовой ответственности за незаконную рубку лесных насаждений (ст. 260 УК РФ) в период с 2016 по 2019 г.

\begin{tabular}{|c|c|c|c|c|c|c|c|c|c|}
\hline 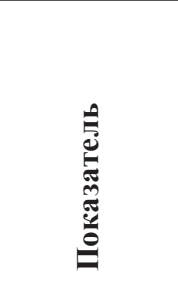 & $\begin{array}{l}0 \\
\frac{1}{0} \\
\frac{1}{4} \\
5 \\
0 \\
0\end{array}$ & 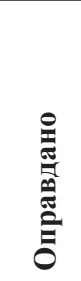 & 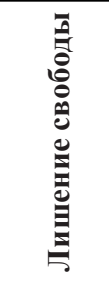 & 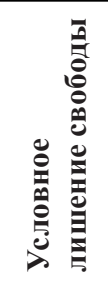 & 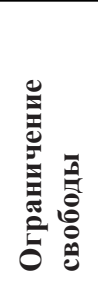 & E્E & 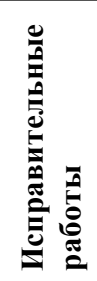 & 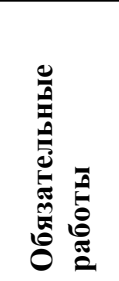 & 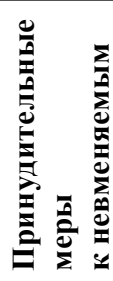 \\
\hline \multicolumn{10}{|c|}{2019} \\
\hline $\begin{array}{c}\text { Всего } \\
\text { по составам } \\
\text { УК РФ }\end{array}$ & 598214 & 1523 & 172914 & 157051 & 20394 & 75200 & 51684 & 100807 & 52460 \\
\hline ч. 1 ст. 260 & 884 & 0 & 12 & 71 & 0 & 207 & 41 & 475 & 384 \\
\hline ч. 2 ст. 260 & 662 & 0 & 17 & 607 & 2 & 29 & 2 & 2 & 247 \\
\hline ч. 3 ст. 260 & 1749 & 5 & 270 & 1376 & 4 & 54 & 7 & 6 & 2 \\
\hline \multicolumn{10}{|c|}{2018} \\
\hline $\begin{array}{c}\text { Всего } \\
\text { по составам } \\
\text { УК РФ }\end{array}$ & 658291 & 1446 & 187794 & 169030 & 22966 & 85760 & 56450 & 116058 & 8171 \\
\hline ч. 1 ст. 260 & 1245 & 0 & 13 & 93 & 0 & 275 & 66 & 683 & 9 \\
\hline ч. 2 ст. 260 & 809 & 2 & 11 & 733 & 4 & 49 & 4 & 7 & 3 \\
\hline ч. 3 ст. 260 & 1976 & 3 & 234 & 1611 & 1 & 67 & 8 & 5 & 9 \\
\hline \multicolumn{10}{|c|}{2017} \\
\hline $\begin{array}{c}\text { Всего } \\
\text { по составам } \\
\text { УК РФ }\end{array}$ & 697174 & 1563 & 197537 & 176557 & 25112 & 90932 & 56421 & 129495 & 8337 \\
\hline ч. 1 ст. 260 & 1339 & 0 & 19 & 87 & 2 & 325 & 79 & 728 & 12 \\
\hline ч. 2 ст. 260 & 806 & 1 & 19 & 697 & 1 & 65 & 1 & 8 & 6 \\
\hline ч. 3 ст. 260 & 2074 & 9 & 263 & 1673 & 4 & 52 & 2 & 5 & 11 \\
\hline \multicolumn{10}{|c|}{2016} \\
\hline $\begin{array}{c}\text { Всего } \\
\text { по составам } \\
\text { УК РФ }\end{array}$ & 740380 & 2640 & 203788 & 184618 & 25368 & 100348 & 53172 & 142084 & 0 \\
\hline ч. 1 ст. 260 & 1483 & 1 & 10 & 80 & 0 & 424 & 100 & 717 & 0 \\
\hline ч. 2 ст. 260 & 928 & 1 & 29 & 790 & 0 & 61 & 7 & 5 & 0 \\
\hline ч. 3 ст. 260 & 2047 & 6 & 216 & 1542 & 2 & 69 & 0 & 2 & 0 \\
\hline
\end{tabular}

санкции части первой статьи» (LesnievskiKostareva, 1998).

Учитывая масштабы незаконной рубки лесных насаждений в стране, мы не беремся утверждать, что основным составом должна стать незаконная рубка в особо крупном размере, но криминообразующим признаком должен быть не значительный, a крупный размер (т. е. превышающий
50 тыс. рублей).-Противостоять незаконным рубкам, причиняющим ущерб до 50 тыс. рублей (включительно), можно и мерами административной ответственности. Конечно, санкции частей первой и второй ст. 8.28. КоАП требуют соответствующей корректировки, а именно: увеличения размеров штрафа, включения альтернативного основного вида наказания - обязатель- 
ных работ 1 и дополнительного наказания (в часть вторую указанной статьи) - конфискации орудия совершения или предмета административного правонарушения. При этом размер штрафа, по нашему мнению, необходимо установить от 40 тыс. рублей до 90 тыс. рублей в санкции части первой и от 60 тыс. рублей до 100 тыс. рублей в части второй ${ }^{2}$. Указанные размеры превышают максимальный размер штрафа (в 5 тыс. рублей), поэтому они должны быть специально предусмотрены для ст. 8.28 в ст. 3.5 КоАП («Административный штраф»).

Что касается обязательных работ, то их размер должен быть установлен от 40 до 80 часов в санкции части первой и от 60 до 120 часов в санкции части второй ст. 8.28. КоАП РФ.

Приведем еще один аргумент в пользу декриминализации «простой» незаконной рубки.

По мнению представителей Министерства лесного хозяйства Красноярского края, в борьбе с «простой» незаконной рубкой необходимо использовать наказание в виде лишения свободы, поскольку взыскать штрафы с виновных, учитывая их материальное положение, чаще всего невозможно. В то же время криминализация незаконной рубки, причинившей ущерб в размере до 10 тыс. рублей, явно противоречит «экономическому подходу» (Stepashin, 2021) к соотношению преступления и наказания. Расходы на реализацию наказания в виде лишения свободы становятся неоправданно высокими: ежегодные расходы на одного осужденного к лишению свободы с учетом всех непрямых расходов по состоянию даже на 2013 г. оценивались в 480 тыс. рублей (Suhovarov, 2012). Если учесть, что лишение свободы будет способствовать и вовлечению «мелких» рубщиков в криминальную среду, установление уголовной ответственности за незаконную рубку в значительном размере противоречит такому условию кри-

\footnotetext{
1 Это альтернативное наказание необходимо в связи с отсутствием у многих «мелких» рубщиков какого-либо дохода.

2 Такие размеры штрафа значительно превышают размер ущерба.
}

минализации, как превышение ожидаемых положительных последствий криминализации ее отрицательных последствий.

В понятие декриминализации нередко включают и процесс признания нецелесообразности уголовно-правовой борьбы с деяниями, признанными преступлениями, поэтому уместно отметить следующее.

По мнению экспертов, к основным причинам незаконных рубок относятся: бедность и безработица, в особенности среди сельского населения и жителей лесных деревень и поселков; чрезмерные и несправедливые ограничения доступа к жизненно важным для населения лесным ресурсам; неэффективная система управления и несовершенное законодательство, а также большой спрос на внутреннем и внешнем рынках на древесину; непрозрачность отношений в лесном секторе и высокий уровень коррупции. Совершенно очевидно, что причинами «простой» незаконной рубки лесных насаждений три последние причины быть не могут. Причинами исследуемого нами деяния в основном выступают две первые. В связи с этим докриминализация или допенализация эффективной мерой противодействия «простым» незаконным рубкам быть не может. «Ни одной стране мира не удалось искоренить незаконные рубки, не искоренив бедность сельского населения, сколь бы жесткими или даже жестокими ни были наказания за эти правонарушения» (Yaroshenko, 2008). Самым эффективными здесь могут быть только меры общесоциального предупреждения. И в Стратегии развития лесного комплекса Российской Федерации до 2030 г. такие меры предусмотрены (Rasporyazhenie Pravitel'stva RF, 2021).

\section{Выводы}

Частичная дополнительная криминализация «простой» незаконной рубки не стала и не может быть эффективной мерой противодействия ей.

В основе частичной криминализации такой рубки в 2008 г. была ошибка правоприменителей в определении объема древесины, полученного в результате «про- 
стой» незаконной рубки. Исправление ошибки диктует необходимость возврата к прежней нижней «границе» значительного размера, т. е. к его легальному определению «превышающий десять тысяч рублей» ${ }^{3}$.

\footnotetext{
3 Заметим, что, предлагая вернуться к прежнему размеру ущерба, соответствующему значительному размеру незаконной рубки (свыше 10 тыс. рублей), И. А. Конфоркин отмечал, что «это мнение основано на анализе судебноследственной практики и на обобщенных показателях средней величины ущерба по данной категории дел» (Konforkin, 2009).
}

Однако части вторая и третья ст. 260 УК РФ (незаконная рубка с квалифицирующими и особо квалифицирующими признаками) вместе применяются чаще части первой, установившей ответственность за «основной» состав преступления, а часть третья иногда применяется в два раза чаще части первой. Следовательно, незаконная рубка в значительном размере подлежит декриминализации, а признаком основного состава должен стать как минимум крупный размер, т. е. превышающий 50 тыс. рублей.

\section{Список литературы / References}

Bykovskij, V.K. (2020). Pravovye i organizacionnye osnovy gosudarstvennogo upravleniya lesami: uchebnik i praktikum dlya sredneg o professional'nogo obrazovaniya [Legal and institutional framework for forest governance: textbook and workshop for secondary vocational education]. Moskow, Izdatel'stvo Yurajt, $262 \mathrm{p}$.

Churakov, D.B. (2017). Protivodejstvie prestupnym posyagatel'stvam na sohrannost' lesnyh i inyh nasazhdenij (ugolovno-pravovye i kriminologicheskie mery). Diss. ...kand. yurid. Nauk [Countering criminal attacks on the safety of forest and other plantations (criminal and criminological measures)]. Moskow, $268 \mathrm{p}$.

Deryuga, A.N. (2011). Obshchestvennaya opasnost' - priznak administrativnogo pravonarusheniya? In Zhurnal rossijskogo prava, 8 (176), available at: https://cyberleninka.ru/article/n/obschestvennaya-opasnost-priznak-administrativnogo-pravonarusheniya/viewer

Dolgih, T.N. (2020). Otvetstvennost' za nezakonnuyu rubku lesnyh nasazhdenij [Liability for illegal logging]. Available at: http://www.consultant.ru/edu/

Durmanov, N.D. (1948). Ponyatie prestupleniya [Concept of crime]. Moskow, 311 p, available at: http:// www.dlib.rsl.ru/01005791721/

Esakov, G.A. (2019). Ekonomicheskoe ugolovnoe pravo: Obshchaya chast' [Economic criminal law: General part]. Moskow, Izd. dom «Vysshaya shkola ekonomiki», 360 p.

Esteticheskie svojstva lesov rekreacionnogo naznacheniya (2019). Available at: http://www.poisk-ru. $\mathrm{ru} / \mathrm{s} 5597 \mathrm{t} 19 . \mathrm{html}$ (accessed 05 March 2021).

Federal'nyj zakon (2003). 162-FZ «O vnesenii izmenenij i dopolnenij v Ugolovnyj kodeks Rossijskoj Federacii». In Rossijskaya gazeta, 252.

Federal'nyj zakon (2008). 145-FZ «O vnesenii izmenenij v stat'yu 260 Ugolovnogo kodeksa Rossijskoj Federacii i stat'yu 8.28 Kodeksa Rossijskoj Federacii ob administrativnyh pravonarusheniyah». Available at: http://www.pravo.gov.ru (accessed 05 March 2021).

Federal'nyj zakon (2017). 206-FZ «O vnesenii izmenenij v Lesnoj kodeks Rossijskoj Federacii i otdel'nye zakonodatel'nye akty Rossijskoj Federacii v chasti sovershenstvovaniya regulirovaniya lesnyh otnoshenij». Available at: http://www.pravo.gov.ru (accessed 05 March 2021).

Fis'kov, I.A. (2019). Obshchestvenno opasnye posledstviya nezakonnoj rubki lesnyh nasazhdenij [Socially dangerous consequences of illegal logging]. In Mezhdunarodnyj zhurnal gumanitarnyh i estestvennyh nauk [International Journal of Humanities and Sciences], 4-3, 203-205.

Fis'kov, I.A. (2019). Ugolovnaya otvetstvennost' za nezakonnoe ispol'zovanie lesov: avtoreferat dis. ... kandidata yuridicheskix nauk [Criminal liability for illegal use of forests]. Vladivostok, $26 \mathrm{p}$.

Forest Europe, UNECE and FAO (2011). In State of Europe's Forests. Status and Trends in Sustainable Forest Management in Europe. Ministerial Conference on the Protection of Forests in Europe, Oslo, Norway, 14-16 June. 
Hilyuta, V.V. (2018). Ekonomicheskoe prestuplenie ili pravonarushenie: poisk kriteriev otlichiya [Economic crime or offense: finding criteria for distinction]. In Rossijskij zhurnal pravovyh issledovanij [Russian Journal of Legal Research], 3 (16), 120-129.

Ivanov, N.G. (2015). K voprosu o kriteriyah kriminalizacii [On the question of criminalization criteria]. Materialy` mezhdunarodnoj nauchno-prakticheskoj konferencii «Ulozhenie o nakazaniyah ugolovnyh i ispravitel'nyh 1845 goda konceptual'nye osnovy i istoricheskoe znachenie» [Proceedings of the International Scientific and Practical Conference «Penal and Correctional Punishment Code 1845 Conceptual Framework and Historical Significance»]. Gelenzhik, 374.

Kaplunov, V.N. (2011). Prestupleniya, posyagayushchie na lesnye resursy: ugolovno-pravovaya $i$ kriminologicheskaya harakteristika (po materialam DFO): avtoref. dis. kand. yurid. nauk [Crimes that encroach on forest resources: criminal legal and criminological characteristics (according to the materials of the Far Eastern Federal District)]. Available at: www.dissercat.com/content/prestupleniya-posyagayushchie-na-lesnye-resursy-ugolovno-pravovaya-i-kriminologicheskaya-kha

Konforkin, I.A. (2009). Ugolovnaya otvetstvennost' za nezakonnuyu rubku lesnyh nasazhdenij [Criminal liability for illegal logging]. Available at: https://www.dissercat.com/content/ugolovnaya-otvetstvennost-za-nezakonnuyu-rubku-lesnykh-nasazhdenii-0.

Krutovskij, K.V. (2021). Les pomozhet nam preodolet' bolezni i stat' dolgozhitelyami. Interv'yu s ekspertom [The forest will help us overcome disease and become centenarians. Interview with expert]. In Zhurnal Novosti Sibirskoj nauki [Journal News of Siberian Science]. Available at: http://www.sib-science. info/ru/news/les-drug-i-tsennyy-25012021

Kuznetsova, N.F. (2010). Znachenie obshchestvennoj opasnosti deyanij dlya ih kriminalizacii i dekriminalizacii [The importance of the public danger of acts for their criminalization and decriminalization]. In Gosudarstvo i pravo [State and law], 6, 68-70, 72, 74-75.

Kuz'michev, E.P., Trushina, I.G., Lopatin, E.V. (2018). Ob “emy` nezakonny`x rubok lesnyx nasazhdenij v Rossijskoj Federacii [Illegal logging in the Russian Federation]. In Lesohozyajstvennaya informaciya [Forest information], 1, 68-70.

Kulakova, V.A., Cherdakova, T.B. (2020). Ugolovnaya otvetstvennost' za nezakonnuyu rubku lesyh nasazhdenij v Rossii i Kitae [Criminal liability for illegal logging in Russia and China]. In Aktual'nye problemy razvitiya zakonodatel'stva $R F$ i KNR [Current problems of the development of legislation of the Russian Federation and China], 565. DOI 10.48344/BSPU.2020.58.71.080.

Lesnievski-Kostareva, T.A. (1998). Differenciaciya ugolovnoj otvetstvennosti. Teoriya i zakonodatel'naya praktika [Differentiation of criminal liability. Theory and legislative practice]. Moskow, Izd-vo NORMA, $287 \mathrm{p}$.

Lesnikov, G.Yu., Lopashenko, N.A. (2005). Enciklopediya ugolovnogo prava [Encyclopedia of Criminal Law]. St. Petersburg, T.1. 695 p.

Lopashenko, N.A. (2014). Analiz principov kriminalizacii na primere kriminalizacii prestuplenij $v$ sfere ekonomicheskoj deyatel'nosti [Analysis of criminalization principles by example of criminalization of economic crimes]. Materialy" V mezhdunarodnoj nauchno-prakticheskoj konferencii «Sovremennye problemy ugolovnoj politiki» [Proceedings of the V International Scientific and Practical Conference «Contemporary problems of criminal policy»]. Krasnodar, 143.

Lopashenko, N.A. (2002). Ekologicheskie prestupleniya. Kommentarij k glave 26 UK RF [Environmental crimes. Commentary to chapter 26 of the Criminal Code of the Russian Federation]. Moskow, $800 \mathrm{p}$.

Lyameborshaj, S.H. (2005). Osnovnye principy i metody ekologicheskogo lesopol'zovaniya: avtoreferat dis.... doktora sel'skohoz. nauk. Mosk. s.-h. akad. im. K.A. Timiryazeva [Basic principles and methods of ecological forest management: autorecording dis.... doctors agricultural. Sciences, Mosk. s.-kh. akad. named after K. A. Timiryazev]. Moskow, 68 p.

Lyasheva, Yu.A. (2008). Obshchestvenno opasnye posledstviya kak obyazatel'nyj priznak ob"ektivnoj storony sostava nezakonnoj rubki lesnyh nasazhdenij [Socially dangerous consequences as a mandatory sign of the objective side of the composition of illegal logging]. In E'Kologicheskoe pravo x environmental lawъ, 6, 25-28. 
Mauro Bologna \& GerardoAquino. (2020). Deforestation and world population sustainability: a quantitative analysis. In Nature Research, 10: 7631. Available at: http://www.nature.com/articles/s41598-02063657-6 (accessed 05 March 2021).

Moratorij na vyrubku lesa v nerestoohrannyh zonah (2020). Available at: http://www.vmeste-rf.tv/ news/senator-talabaeva-prizvala-vvesti-moratoriy-na-vyrubku-lesa-v-nerestookhrannykh-zonakh/ (accessed 05 March 2021).

Nezakonnye vyrubki rossijskogo lesa: masshtab problemy i chto s etim delat'? (2017). Centr ekonomicheskih i politicheskih reform. Available at: https://rusrand.ru/analytics/nezakonnye-vyrubki-rossiyskogo-lesa-masshtab-problemy-i-chto-s-etim-delat (accessed 05 March 2021).

Nechevin, D.K., Kolodkin, L.M. (2020). Obshchestvennaya opasnost' prestupleniya: genezis ponyatiya i problema izmereniya i otgranicheniya ot administrativnogo pravonarusheniya x Public danger of crime: the genesis of the concept and the problem of measuring and delineating from an administrative offenseъ. In Administrativnoe pravo i process [Administrative law and process], 1, 14-21. DOI: 10.18572/2071-11662020-1-14-21.

Nikolaev, A.M. (2010). Istoki i perspektivy formirovaniya obshchej teorii kriminalizacii deyanij s uchetom predelov ih obshchestvennoj opasnosti [Origins and prospects for the formation of a general theory of criminalization of acts, taking into account the limits of their social danger]. In Aktual'nye problemy rossijskogo prava [Current problems of Russian law], 3, 244-251.

Novosyolov, A.S. (2016). Ekologicheskie aspekty lesopol'zovaniya: uchebnoe posobie [Environmental aspects of forest management: training manual]. Vologda, $88 \mathrm{p}$.

Plohova, V.I. (2003). Nenasil'stvennye prestupleniya protiv sobstvennosti: kriminologicheskaya $i$ pravovaya obosnovannost' [Non-violent crimes against property: criminological and legal validity]. St. Petersburg, Izd-vo «Yuridicheskij centr Press», 328 p.

Ploshchad' lesnyh zemel'. Edinaya mezhvedomstvennaya informacionno-statisticheskaya sistema (2015). Available at: http://www.fedstat.ru/ indicator/data.do?id=38194 (accessed 05 March 2021).

Polnyj kurs ugolovnogo prava: v 5 t. T.1 Prestuplenie i nakazanie (2008) [Full course of criminal law: in 5 tons. T. 1 Crime and punishment]. St. Petersburg, Yurid. centr Press, 672 p.

Popov, I.V. (2014). Prestupleniya protiv prirodnoj sredy: teoreticheskie osnovy i praktika primeneniya. Avtoreferat dissertacii na soiskanie uchenoj stepeni doktora yuridicheskih nauk [Crimes against the natural environment: theoretical foundations and practice of application. Abstract of dissertation for the degree of Doctor of Law sciences]. Ekaterinburg, 46 p.

Postanovlenie Pravitel'stva RF (2007). 273. «Ob ischislenii razmera vreda, prichinennogo lesam vsledstvie narusheniya lesnogo zakonodatel'stva». In SZ RF. 20. St. 2437.

Postanovleniya Konstitucionnogo Suda RF (2015). 12. Available at: http://www.pravo.gov.ru (accessed 05 March 2021).

Proekt federal'nogo zakona (2008). 490497-4 «O vnesenii izmenenij v stat’yu 260 Ugolovnogo kodeksa Rossijskoj Federacii i stat'yu 8.28 Kodeksa Rossijskoj Federacii ob administrativnyh pravonarusheniyah». Available at: http://www.garant.ru/products/ipo/prime/doc/3035309/ (accessed 05 March 2021).

Prozumentov, L.M. (2009). Obshhestvennaya opasnost' kak osnovanie kriminalizacii (dekriminalizacii) deyaniya [Public danger as grounds for criminalization (decriminalization) of an act]. In Vestnik Voronezhskogo instituta MVD Rossii [Bulletin of the Voronezh Institute of the Ministry of Internal Affairs of Russia], 4, 18-24.

Prozumentov, L.M. (2014). Osnovanie kriminalizacii (dekriminalizacii) deyanij [Grounds for criminalization (decriminalization) of acts]. In Vestnik Tomskogo gos. un-ta. Pravo [Bulletin of Tomsk State Unt. Right], 4 (14), 82.

Pudovochkin, Yu.E. (2019). Ponyatie, kriterii i predely ucheta obshchestvennoj opasnosti prestupleniya sudom [The concept, criteria and limits of consideration of the public danger of a crime by a court]. In Sbornik materialov VII-oj Mezhdunarodnoj nauchno-prakticheskoj konferencii «Ugolovnaya politika $i$ pravoprimenitel naya praktika» [Collection of materials of the VII International Scientific and Practical Conference «Criminal policy and law enforcement practice»]. St. Petersburg, 57-67. 
Rasporyazhenie Pravitel'stva $R F$ (2021). 312. «Ob uterzhdenii strategii razvitiya lesnogo kompleksa Rossijskoj Federacii do 2030 goda». Available at: http://www.government.ru/docs/41539/ (accessed 05 March 2021).

Schyotnaya palata ocenila ushcherb ot nezakonnoj rubki lesov (2019). In Parlamentskaya gazeta. Available at: http://www.pnp.ru/economics/schyotnaya-palata-ocenila-ushherb-ot-nezakonnoy-rubki-lesov. html (accessed 05 March 2021).

Selyakov, N.A. (2010). Kriminologicheskie i ugolovno-pravovye mery protivodejstviya nezakonnoj rubke, unichtozheniyu ili povrezhdeniyu lesnyh nasazhdenij: na primere Severo-Zapadnogo federal nogo okruga Rossijskoj Federacii: avtoreferat dis. ... kandidata yuridicheskix nauk [Criminological and criminal legal measures to combat illegal logging, destruction or damage to forest plantations]. Moskow, $30 \mathrm{p}$.

Sharipova, O.V. (2006). Ugolovnaya otvetstvennost' za nezakonnuyu porubku derev'ev i kustarnikov, unichtozhenie ili povrezhdenie lesov: Po materialam Dal'nevostochnogo regiona: avtoreferat dis. ... kandidata yuridicheskix nauk [Criminal liability for illegal cutting of trees and shrubs, destruction or damage of forests]. Omsk, $19 \mathrm{p}$.

Shuplecova, Yu.I. (2018). Pravovoe regulirovanie lesnyh otnoshenij v Rossijskoj Federacii: Monografiya [Legal regulation of forest relations in the Russian Federation: Monograph]. Moscow, 213 p.

Soveshchanie o razvitii i dekriminalizacii lesnogo kompleksa (2020). Available at: http://www.kremlin.ru/events/president/news/64116 (accessed 05 March 2021).

Stepashin, V. M. (2021). Ekonomicheskie izderzhki ugolovnoj repressii. In Ugolovnoe pravo: strategiya razvitiya $v$ XXI veke: materialy XVIII Mezhdunarodnoji nauchnoji praktichescoji konferentsii. Moskow, RG-Press, $776 \mathrm{p}$.

Sudebnaya statistika $R F$ (2021). Available at: http://stat.xn----7sbqk8achja.xn--plai/stats/ug/t/14/s/17 (accessed 05 March 2021).

Suhovarov, K.S. (2012). Nakazanie ssylkoj v kachestve al'ternativy lisheniyu svobody [Punishment by reference as an alternative to deprivation of liberty]. In Istoriya gosudarstva i prava [history of state and law], 20, 11-14.

Ter-Akopov, A.A. (1999). Ugolovnaya politika rossijskoj Federacii: uchebnoe posobie [Criminal policy of the Russian Federation: training manual]. Moskow, 58 p.

Tobolkin, P.S. (1983). Social'naya obuslovlennost' ugolovno-pravovyh norm [Social conditionality of criminal law]. Sverdlovsk, $177 \mathrm{p}$.

Tolkach, O.V. (2015). Vodoreguliruyushchaya i pollyutanto-deponiruyushchaya rol' lesov (na primere Srednego Urala) [Water-regulating and pollutanto-depositing role of forests (using the example of the Middle Urals)]. ... Dis. ... dokt. sel'skohoz. nauk. Ekaterinburg, 305 p.

Val'kovskaya, V.V., Razgon, A.M. (2017). Les kak blago i istochnik bogatstva: filosofsko-ekonomicheskij ocherk [Forest as a good and source of wealth: a philosophical and economic essay]. In Ekologicheskaya politika. Vlast' i upravlenie na Vostoke Rossii [Environmental policy. Power and governance in the East of Russia], 2 (79), 165.

Yablokov, A.V., Ostroumov, S.A. (1983). Oxrana zhivoj prirody`: problemy` i perspektivy` [Wildlife conservation: challenges and perspectives]. Moscow, $271 \mathrm{p}$.

Yaroshenko, A.Yu. (2008). Prichiny' nezakonny`x rubok [Causes of illegal logging]. In Materialy`kruglogo stola $v$ Sovete Federacii "Pravovoe obespechenie bor' by" s nezakonny'mi rubkami lesa» [Materials of the round table in the Federation Council «Legal support for the fight against illegal logging»]. Available at: http://www.refdb.ru/look/2330534.html (accessed 05 March 2021).

Zhevlakov, E.N. (2002). Ugolovno-pravovaya ohrana okruzhayushchej prirodnoj sredy v Rossijskoj Federacii [Criminal law protection of the natural environment in the Russian Federation]. Available at: http://www.garant.ru/

Zherebkin, G.N. (2011). Otvetstvennost' za nezakonnuyu rubku lesnyh nasazhdenij. Analiz nelegal'nyh rubok na rossijskom Dal'nem Vostoke i metodika ih rassledovaniya [Responsibility for illegal logging. Analysis of illegal logging in the Russian Far East and the method of their investigation. Composition of the Far Eastern Federal]. Moskow, Vsemirny’j fond dikoj prirody` (WWF), 136 p. 